\title{
Indian Railways: Rail Ways for Indians
}

Gopalakrishnan Narayanamurthy, Indian Institute of Management Kozhikode (IIMK) Prof. Vijay Pereira, Portsmouth Business School

Indian Railways (IR), world's largest commercial employer, maintains its competitive advantage over other transportation facilities through affordable price for Indian population with diverse economic background and accessible boarding points. One of the primary factors that were instrumental in making it achievable remains the 'people side' of IR. After celebrating IR's $160^{\text {th }}$ anniversary in 2013, Chief Personnel Officer (CPO) of each IR zone wished to revisit the HR practices followed to understand the transformations that has happened in past to reach at the current state and how they can be improved or sustained for attaining maximum efficiency in future. In addition, the IR board plans to commence operations of the ERP system by establishing computer kiosks at various stations and terminals across India. These initiatives were resisted by the staff due to fear of job losses and insecurity. CPOs were thinking about devising certain new HR policies and changes to the existing HR policies through which the resistance of staff can be minimized.

\section{HISTORY OF IR}

In 2013 , India celebrated the $160^{\text {th }}$ anniversary of the first train journey on its soil, 25 years after the first ever train journey, in Britain. ${ }^{1}{ }^{2}$ On April 16 1853, a locomotive with 14 carriages carrying 400 people left Bombay (today Mumbai) to a 21-gun salute and made its way to Thane, $34 \mathrm{~km}$ (21 miles) away. From then the railway network connecting different places grew very fast. ${ }^{3}$ Some of it was built by the British, some by the then princely states, with many of the network's main trunk routes were laid by private companies. ${ }^{4}$ In 1924 , the entire IR system including its construction, operation, and financing were brought under the control of the British Indian Government. 
IR was often credited with an important role in integrating not just the Indian economy, but also in helping to create the Indian nation itself. ${ }^{6}$ In support, Madhav Rao (1828-1891) - the Chief Minister of the Princely States of Travancore (1858-1872), Indore (1873-1875) and Baroda (1875-1882) once mentioned about IR the following:

"What a glorious change the Railway has made in long and neglected India! The young generation cannot fully realize it. In passing from the banks of Tambrapurny to those of the Ganges, what varied scenes, what successive nationalities and languages flit across the view! Tamil, Telegu, Canarese, Marathi, Guzerati, Hindustani, Bengali speaking populations which had been isolated for unmeasured ages, now easily mingle in civilised confusion. In my various long journeys it has repeatedly struck me that if India is to become a homogeneous nation, and is ever to achieve solidarity, it must be by means of the Railways as a means of transport, and by means of the English language as a medium of communication". 8

Using multi-gauge network of broad, metre and narrow gauges, IR operates both long distance and suburban rail systems. ${ }^{9}$ IR has locomotive and coach production facilities, public sector undertakings (PSUs) and various other movable and immovable assets. Ministry of Railways of China and IR happens to be the only few remaining monolithic railways. ${ }^{10}$

By 1900, IR had a permanent workforce of 338,041 employees already on its rolls apart from the 200,000 construction workers among many others. ${ }^{11}{ }^{12}$ By 1920, its employee count doubled to $710,000 .{ }^{13}$ By 1947 , the year of India's independence, there were 42 rail systems and in 1951 the systems were nationalized as one unit, becoming one of the largest networks 
in the world. ${ }^{14}$ IR employee count in 2013 was approximately 1.7 million including 1.4 million permanent employees and 300,000 casual workers (Exhibit 1 lists the number of staff and expenditure on staff in IR from 1950-2010). ${ }^{15}{ }^{16}$ Being the largest publicly-owned enterprise, they have been supported by the exchequer. However since the early 1990s when the liberalization movement started the railways have had to operate increasingly as a commercial rather than a social organization. ${ }^{17}$ After several years of debating whether to privatize the IR, following on the lines of the US and UK, in 2001 the Government of India were almost ready to privatize the sector. ${ }^{18} 1920$

\section{IMPORTANCE OF IR}

The railways have played a critical role in catalyzing the pace of economic development and continued to be an integral part of the growth engine of India. They have been chugging along transporting people and freight to almost all parts of India. ${ }^{21}$ They have also been the backbone of India's transportation sector and "constitute the principal mode of transport in India". ${ }^{22}$ They supplied the basic means of movement and were seen as the lifeline of the nation, so much so that "most Indians would have used the railways at some point of their life as a means of transportation". ${ }^{23}$ Nonetheless they have been an unsung hero in India's economic growth story.

IR has a state monopoly on India's rail transport. Perhaps IR will be the only railways in the world which has the privilege of presenting its own budget separately to parliament, a week before the general (national) budget. IR continues to be one of the world's largest and busiest rail networks. It moves more than 2 million tonnes of freight and nearly 18 million passengers per day across different routes totaling to a length of more than $63,327 \mathrm{~km}$ or 39,500 miles (Exhibit 2 documents the details of number of passengers and earnings at sub- 
urbans for few key zones). ${ }^{24}{ }^{25}$ As of 2008, IR owned almost 8,300 locomotives, 45,000 coaches, and 225,000 wagons and ran more than 18,000 trains daily, including about 8,984 passenger trains and 9,387 goods trains. ${ }^{26}$ Net Revenue Receipts of Railways were at INR 6,346.14 crore. The freight earnings went up from INR 56,911.51 crore in 2009-10 to INR $60,687.05$ crore in 2010-11, registering a growth of $6.63 \%$. In 2010-11, 16,638 wagons, 527 locomotives, and 3,660 coaches were acquired by IR. ${ }^{27}$ IR owns about 4.59 lakh hectares of land. About $90 \%$ of the land is under Railways' operational and allied usage such as laying of new lines, doubling, gauge conversions, track, stations, workshops, staff colonies, etc. Track constitutes the basic infrastructure of a railway system and bears the burden of coping with ever increasing traffic. High speed and heavy axle load operation on IR has necessitated upgradation of the track structure. Sleepers are also being upgraded from wooden, steel and CST-9 materials to PSC sleepers. ${ }^{28}$

IR till date remains the world's largest commercial or utility employer, with approximately 1.7 million employees. Pay and allowances of regular employees account for about $45 \%$ of the total working expenses of railways (excluding appropriation to the depreciation reserve fund and the pension fund - for its 1 million pensioners). On an average it spends Rs.520 million (\$11.19 million) as expenditure on staff per day. Traffic carried by IR has exhibited optimistic growth averaging $9 \%$ per annum in case of freight and $8 \%$ in case of passengers over the last five years. ${ }^{29}$ By the end of Eleventh Five Year Plan in 2011-2012, Ministry of Railways had set itself an ambitious target of carrying 1100 million tonnes of freight and 8.4 billion originating passengers. New initiatives underway in the Twelfth Five Year Plan (2012-2017) includes Western and Eastern Freight Corridor, the Mumbai Elevated Rail Corridor and the High Speed Corridor. ${ }^{30}$ Dedicated Freight Corridors on the Western and the Eastern routes involves construction of $3,338 \mathrm{kms}$ of dedicated freight lines to carry 
predominantly coal and steel on the Eastern corridor. Newer technology in signaling, train communication, track-maintenance and operations are being planned to be introduced. These initiatives target to improve the Railways capacity which has lagged far behind than needed, especially given the need to shift from road transport to rail in the interest of improving energy efficiency and reducing the carbon footprint.

\section{ORGANIZATIONAL STRUCTURE OF IR}

The IR comprises 16 zones which include 67 divisions spread across the nation. Apart from this they have several PSUs under their control and also possess their own locomotive and coach production facilities. IR being a self-sufficient organization holds, maintains and staffs their own manufacturing, maintenance, security force, schools, hospitals, housing, cooperative banks, cooperative societies and recreation clubs to name a few. Activities at zones, divisions, production units and PSU's were overseen by the Railway Board, under the Ministry of Railways in New Delhi. The Railway Board has six members headed by a Chairman. Of these one board member, called 'member-staff' has a place at the 'table'. General Managers (GM) head each of the 16 zones. They report directly to the Railway Board. The zones further divide into 67 divisions under the control of Divisional Railway Managers (DRM). DRM's in turn report to the GM's. Divisional officers of engineering (electrical, mechanical, signal and telecommunication), accounts, personnel, operating, commercial and safety branches report to the respective DRM, responsible for operating and maintaining the assets (as shown in exhibit 3) ${ }^{31}$ Individual stations and the train movement through the track territory within are controlled by Station Masters (SM). SM stands further down in the administrative ladder - reporting to the Divisional Operating Manager (DOM). In addition to the zones, a General Manager (GM) heads each of the six production units 
(PU's) who also reports directly to the Railway Board. Certain PSU's were headed by Managing Directors (MDs) who again report to the Railway Board.

Employee chosen to work for IR should have the willingness to work in a predetermined hierarchy. ${ }^{32}$ Similar case prevails in any other Indian government service where hierarchy needs to be adhered quite closely. It remains most unlikely in the case of private sector. Railway employees were always on the move to fulfill their responsibility of ensuring safety and protection of passengers and their belongings. At most care was given to not compromise on passenger safety in any manner. Railway employees were seen to be flexible enough to be able to adapt to different situations and different people as they interact with many people on daily basis. But while doing that their inner discipline ensured that they stick to their roles and responsibility towards the users of IR. Hierarchy and discipline were seen to be taken very seriously at IR. Again the size, scale, vastness and complexity of the organization have over time led to the prevalence of this culture.

As in the case of any other Indian government service, a person chosen to work in IR should have the willingness to work in a predetermined hierarchy. Unlike the private sector, hierarchy will be adhered to quite closely in the government sector. As the railways were always on the move so were many of its employees. The railway employees were responsible for the safety of the passengers and their belongings. Care was also taken that they do not compromise with passenger safety in any manner. In the course of duty, railway employees were seen to interact with many people and hence were seen to be flexible enough to be able to adapt to different situations and different people. But while doing that they were governed by an inner discipline which ensures that they stick to their responsibility towards railway users and the department. Hierarchy and discipline were seen to be taken very seriously at IR. 
Again the size, scale, vastness and complexity of the organization have over time led to the prevalence of this culture.

\section{HR MANAGEMENT DEPARTMENT IN IR}

Staffing for IR constitutes 1.4 million regular employees and 300,000 casual workers. Railway employees were classified into 4 classes of which 800,000 were class IV, 600,000 were class III, and 8,500 were classes I and II. Hence classes III and IV constitute $99 \%$ of the total workforce - with less than $1 \%$ comprising officers and managers in classes I and II. No separate department in IR was established until 1924 to deal with staff matters and 'Executive Officers' had to deal with those matters till then. In 1946, the Railway Board decided to establish a distinct Railway Service with its own cadre to be known as 'Establishment Department' to cater to the increasing volume and complexity of labor. In 1945 and 1947, seventeen candidates were recruited through Central Services Examination. However in 1949 the Railway Board did away with recruiting the above. Thereafter from 1956 to 1960 there were 'Seconded Personnel Officers' (deputed from the line) - who looked after staff/personnel matters. In 1966 the First Administrative Reforms Commission was set and it recommended that a separate 'Department of Personnel' should be set up. However it was only in the 1972 railway budget that it was decided for a separate cadre for Personnel Management to cope with the modern management techniques. ${ }^{33}$

From 1980 onward the Union Public Service Commission (UPSC) started recruiting Indian Railway Personnel Services (IRPS) officers, a small cadre with around 320 officers (called Group ' $A$ ' officers) on roll. They were responsible for establishment and personnel management, looking after the industrial relations, administration of labor laws, administration of welfare schemes, legal matters pertaining to staff and personnel HR 
development, pension matters of more than a million retired railway personnel. These officers were assisted by Group 'B' Personnel Officers (promotes from classes III and IV), several Group 'C' Personnel and Welfare Inspectors, Office Superintendents and Clerks posted in different zones, divisions, production units and PSU's all over India. Interestingly the 'Accounts' Department remains the only department responsible for its own staff matters. All other department's staff matters were looked after by the Personnel Department. Thus the Personnel Department and its employees constitute a fraction of its overall workforce and were responsible for all personnel and HR matters as detailed above. An interesting anecdote by an Indian railway personnel officer wherein very early in her career she was attending a HR training course alongside HR managers and directors from different private and public sectors sums it up as

"Whilst attending this course we were asked to introduce ourselves, our position and the number of staff we were responsible for. I was one of the last few and when I heard the positions and the number of staff my fellow HR professionals in both the sectors were responsible for I was surprised - and when I said I was merely a junior personnel officer for the Indian railways responsible for a small division comprising 60,000 staff, everyone else was stunned and asked if this was really true? '- Personnel Manager (Western Railway).

This portrays the vastness and the colossal scale of managing people in this organization. In terms of comparing and contrasting the HR practices geographically, no major differences were found. There were some cultural differences between the railway zones. National language Hindi was used more frequently in north when compared to English. South and west/central zones were more frequently using English language and were found to be more 
technologically advanced. They were the first to use touch screen kiosks for employees to check the status of their provident fund, loans, savings balance etc. Also the Western Railways were chosen as the first for the ERP systems project which is planned to be implemented on all zones.

\section{RECRUITMENT AND SELECTION IN IR}

Being a bureaucratic organization there were fixed promotion or advancement routes. IR classifies its employees into four classes (as listed in exhibit 4). Central Railway’s Personnel Manager explains the selection procedure through the following quote:

"Selection to class IV posts is by the railway administrations through Selection Boards. Class III posts are usually made through the Railway Service Commissions by open competition on all India bases. Group 'A' and 'B' Officers (class I and II) is through a competitive examination held by the Union Public Service Commission. Promotions from the lower grades are based on 'seniority-cum-suitability' and in higher grades it is by 'selection on merit only".

For all the posts in all categories, a stringent medical examination was carried out by the railway doctors in railways hospitals - prior to final appointment. Interestingly in IR, emphasis was seen on character and antecedents of potential employees. Comprehensive training at the initial/induction stage remains compulsory for the recruits. Most positions have one year probation - though this varies for departments and positions. Different recruitment and selection routes exist to officers in different departments/branches or disciplines as classes I and II officers (as listed in exhibit 5). Recruitment to class III and in some cases class IV in the IR was on a national basis - through the RRB. Currently there are 19 RRB's 
across the country which are Ahmedabad, Ajmer, Allahabad, Bangalore, Bhopal, Bhubaneswar, Chandigarh, Chennai, Gorakhpur, Guwahati, Jammu and Srinagar, Kolkata, Malda, Mumbai, Muzaffarpur, Patna, Ranchi, Secunderabad, and Thiruvananthapuram.

In 1998, Railway Board set up the Railway Recruitment Control Board (RRCB) with the objectives listed in exhibit 6. A typical recruitment process was explained by a Personnel Manager from North-Central Railway as quoted below:

"A typical recruitment process would involve a railways division sending a requisition for vacancies to the RRB's. The RRB then allocates schools for exam centre and dispatches question paper through selected agencies. The respective divisions then execute exams and the evaluation set is given to the agency.... They then dispatch the results directly to RRBs who in turn publish the result online".

IR also encourages sports persons with outstanding and recognized national and international track who could represent them in their respective field of sport. Another unique concept within the IR was the 'compassionate appointment' of a dependent child i.e., son/daughter or wife (above 18 years, subject to basic fulfillment of employment conditions), on the death of an employee. It was also reported that there has been an increased transparency in recruitment and selection leaving less scope for corruption and malpractices. For instance, current job openings/vacancies were posted on the IR website. IR took workforce planning very seriously. It has witnessed dynamic changes in technology and modernization, electrification, computerization, mechanization of track maintenance, etc. These changes were taking place at an electric pace and to meet the challenges of its traffic requirements, increased competition and changing environment, systematic workforce planning were seen 
to be essential. In response to it, IR carried out a category-wise analysis of staff, to identify surplus staff and to arrange required categories of manpower. Due to automation and modernization, the reduction in the total employee strength has been approximately $1 \%$ per annum. The total employee strength on roll has reduced from 1.7 million employees in 1999 to 1.4 million in 2009 and to 1.3 million in 2012 . Thus, overall in the context of recruitment and selection in the IR, there was evidence of it being highly formalised and structured. This was again for reasons of its size, vastness and complexity of operations.

\section{TRAINING AND DEVELOPMENT}

All new recruits had to undergo training when they join and especially gazetted officer's get trained at one of the seven 'Centralised Training Institutes' (CTIs) listed in exhibit 7. Gazetted officers also undergo management training courses both in India and abroad. In India, they were conducted at the prestigious Indian Institutes of Management (IIM's). Recently IR has signed a five year contract with HEC Paris, a global business school. HEC Paris will provide international learning programmes to IR's middle and senior management and will become IR's biggest supplier of external learning for managers. Training needs of IR staff is explained through the following quote from a Personnel Manager of Central Railway.

"The training needs of non-gazetted staff are being taken care of by approximately 200 training centres located over IR. These training institutes and centres specialize in various functional training based on the different functions or departments. For example - for operating staff there are drivers training, guards training, motormen training, etc. Apart from receiving training when they start out in their careers railway personnel also receive periodic training in the form of refresher courses or when new methods or technology are introduced" 
The identification of a training need was seen to be the outcome of performance appraisal which was an annual exercise. An annual 'training calendar' (calendar year - January to December), was planned at the board level, which then percolated to the different zones and respective zonal training centres. This training calendar was rolled out every 5 years. The zonal training centres request for nominations from the divisions and schedule the training. The nominations were then sent from the divisions to the headquarters and the zonal training centres for administration of training to the employees on the said date. It was learnt that a few employees at all levels in the IR resist training outside their respective division/headquarters, as they were required to stay away from their families till the duration of the training was completed. Hence employees prefer in-house training to outstation training at the zonal training centres. However training attendance were compulsory for all technical 'running staff', i.e., staff associated with running of trains. A personnel manager from South Central Railway mentioned that:

"The duration of training programs maybe from 2 days to 15 months, where to delve into 1 subject, there are at least 6 to 7 sub-category training programs held. A training centre is a place where employees experience sharing of information with other employees. This widens their learning experience"

Post training, the training centres conduct examinations - both written and practical - to measure the effectiveness of training. It was also learnt that another way the railways measure effectiveness of a training programme was through the 'simulation exercise' as it was practiced in the Sabarmati locomotive maintenance section in the state of Gujarat. The 'running' staff were expected to undergo a 'simulation' test where their abilities to run a train 
will be tested. The Sixth Pay Commission had also introduced training programmes such as 'train the trainer', wherein employees trained at the zonal training centres may train staff internally at the division. Thus overall learning, training and development were available at all levels. It was also paramount for the organization as it concerns transportation and hence safety.

\section{COMPENSATION \& BENEFITS}

The structure of emoluments and conditions of service of railway employees, like those of other Central Government employees, were reviewed periodically by the 'Pay Commissions' appointed by the Government from time-to-time. Employees on rolls of the regular establishment of the Railways were placed on time scales of pay. Annual increments were drawn as a matter of course except on reaching an 'efficiency bar'. 'Allowances' provided were capturing the cost of living index (as in the case of dearness allowance). Employees compensation on account of unusual working hours or special nature of duties (such as nightduty allowance or running allowance), or inhospitable or expensive place of posting (such as bad climate allowance, hill allowance, house rent allowance, city compensatory allowance) were also provided. Railway employees were classified as 'intensive', 'continuous', 'essentially intermittent' and 'excluded' based on the number of hours of work (as explained in exhibit 8). The rules governing the pay and allowances, leave entitlement, retirement-cumdeath benefits, etc., of railway employees were collectively known as the 'establishment rules', and were embodied in the IR 'establishment codes' and the IR 'establishment manual'. Permissible deductions can be made from the wages of an employee in the form of Income tax, Employees State Insurance, Provident Fund, and death-cum-retirement fund. A quote below by a Personnel Manager from South-Central Railway zone captures the historical perspective of this reward system: 
"To increase the productivity of workshops and Production Units and creating incentive for the employees and their supervisors, an incentive scheme like a Performance Related Pay (PRP) has been in existence on the Railways for a number of years. It was initially introduced in Chittaranjan Locomotives. Time is the yardstick for measuring the work and productivity. 'Allowed time' is fixed after a detailed time study and includes allowances for fatigue, general handling, etc., extra allowance to enable a workman of average ability to earn 33.33 per cent over and above his basic wages".

The hours of work, periodic rest and overtime entitlement of all railway employees (including casual workers, except those employed in the workshops or on the ferries) were governed by the hours of employment regulations (H.E.R.). The genesis of the H.E.R. dates back to the IR (Amendment) Act, 1930 which was enacted to implement the provisions of Washington Convention No. 1 of 1919, ratified by the Government of India in 1921, and Geneva Convention No. 14 of 1921 which was ratified by the Government of India in 1923. In 1956, the Indian Railways Act was amended by the introduction of Chapter VI-A, and in 1961, the Central Government framed rules under Section 71-E of the same Act and these rules were published under the title 'Railway Servants (Hours of Employment) Rules, 1961'.

On an average the IR spends Rs.520 million (\$11.19 million) as expenditure on its staff per day (Indian Railway Budget Report, 2008/2009). Payments however were made on a monthly basis and the mode of payment was through banks and in some circumstances was paid in cash. All gazetted staff were paid through banks but non-gazetted staff can opt for cash or bank payment. The management though encourages bank payments, but practically this was 
not seen to be possible with the vastness of its operations, especially for employees posted in rural or remote places.

Concept of productivity linked bonus (PLB) was introduced in IR, first of its kind attempt in an Indian Government undertaken department. Personnel manager of Western Railway explains the concept of PLB as quoted below:

"The main consideration at that time was the important role of the Railways as an infrastructural support in the performance of the economy as a whole. In the overall context of railway working, it was considered desirable to introduce the concept of PLB as against the concept of 'Bonus' on the lines of 'The Payment of Bonus Act1965'. Even though the Payment of Bonus Act does not apply to the Railways, yet the broad principles contained in that Act were kept in view for the purpose of determining the 'wage/pay ceiling: definition of 'salary'/'wage', etc'.

The PLB scheme came into force in railways from the year 1979-1980 and was evolved in consultation with the two recognized federation's viz. the 'All India Railway men's Federation' (AIRF) and the 'National Federation of Indian Railway men' (NFIR) - with the approval of the Cabinet. The scheme is reviewed for every three years.

The recent Sixth Central Pay Commission (CPC) has recommended all departments (including the railways) to replace the existing PLB schemes with performance related incentive scheme (PRIS) (Sixth CPC Report). Departments where PLB remains applicable and infeasible to implement PRIS immediately, the existing PLB schemes can be continued in a modified manner such that the formula for computing the bonus has a direct nexus with 
the increased profitability/productivity under well-defined financial parameters. In case the PRIS was not implemented immediately in ministry of railways, sixth CPC in their report with respect to the railway's PLB scheme, proposed a new formula based on financial parameters where profit was computed as per the established principles of commercial accounting, wages with appropriate adjustments for increases, the impact of the capital investment, element of subsidy, etc. The government has decided to examine the scenarios relating to the PLB schemes separately, but has accepted the recommendation regarding PRIS. Thus individual ministries/departments had to devise PRIS in accordance with their own organizational structure and needs as per guidelines to be issued by the nodal ministry. PLB were paid to all classes III and IV staff on the IR. In 2008 they were paid 73 day's pay and 75 days in 2009 - (1.38 million employees were on the rolls in 2008 and 1.35 million in 2009. ${ }^{34}$ PLB was calculated based on the productivity indices reflecting Railways performance. 75 days' of PLB to railway employees has been estimated to be $\$ 192$ million. This was normally paid to employees in the month of October before the Hindu festival of 'Dushera', which comes before the festival of 'Diwali'.

Over the years, IR has downsized the staff on payroll from about 1.58 million in 1999 to about 1.41 million in 2006, downsized by around $10 \%$. Downsizing reduced the overall expenditure in 2006 by at least $\$ 431.22$ million in comparison to the staffing levels in 1999 . In 1998, introduction of Fifth Pay Commission increased the expenditure on staff and pension payments by almost $35 \%$ in just one year. Pay and conditions within IR was seen to be a complex structure with the given size, scale and vastness of its operations. 


\section{MANAGEMENT AND ORGANIZATIONAL CULTURE}

Geographic regions of India have diverse culture and distinct languages. ${ }^{35}$ States in India's federal system reflects a dominant ethnolinguistic group, but these groups are in turn divided by caste, religion, food, arts, and a host of socioeconomic cleavages. Indian people professes all the major religions of the world and therefore India is called as "the epitome of the world". In 1956, with a more general reorganization on a linguistic basis, the principle of language as the basis for state boundaries was broadly accepted. The organization of states on a linguistic basis provides the framework for expanded political participation. India has more than a dozen major languages spoken across the country. Hindi, a language spoken by almost 40 percent of Indian population, was recognized by the Constitution of 1950 as the official language. ${ }^{36} 378^{\text {th }}$ Schedule of the Constitution of India recognizes 22 languages to be spoken by people in India. Most of the languages spoken in North India belong to the Indo-Aryan family, while the languages of the South belong to the Dravidian family. ${ }^{38}$ India has been known as a "Veritable tower of babel" or in the words of A.R. Desai "India presents a spectacle of museum of tongues". ${ }^{39}$ Indian Wealth Distribution remains highly skewed. $38.35 \%$ of the market cap comes from the states of Maharashtra and $27.82 \%$ comes from Delhi NCR. Other key states where there is significant market cap are: Karnataka (7.74\%), Gujarat (7.48\%), Andhra Pradesh (4.95\%), Tamil Nadu (4.02\%) and West Bengal (3.83\%). These top 7 states represent about $94.20 \%$ of total market cap of BSE 500. Further, within these states, there is significant concentration of market cap in the leading city of that state. Mumbai represents $94.61 \%$ of Maharasthra's market cap, Bangalore represents $91.71 \%$ of Karnataka's market cap, Hyderabad represents $98.14 \%$ of Andhra Pradesh's market cap, Kolkata represents $100.00 \%$ of West Bengal's market cap. These top 7 cities represent $85.71 \%$ of the total market cap of BSE $500 .^{40}$ This unequal distribution of wealth between the states leaves some of the wealthy states to be well developed and poor states to be least 
developed. Disparity in development leads to difference in access to basic necessities such as education, healthcare, etc. which in turn impacts the quality of manpower obtained from different states. IR which employs people from different states across the country has to account for the complex mixture of culture, language, education, and training in any of its new initiative.

India being a country with diverse culture and background, IR had to have in place a standardized and structured code of conduct for running the system efficiently beyond the differences between the employees and their origin. Inevitably, the multifarious spheres of railway operation across the country impose certain responsibilities and obligations on the railway employees. All railway personnel were expected to observe a general code of behavior as embodied in the relevant conduct rules in regard to various matters such as employment of near relatives in private undertakings enjoying government patronage, joining of associations or unions, indulging in criticism of government and unauthorized communication of information, and maintaining and furnishing a record of movable and immovable assets. As an employee of Central Government in the ministry of railways or in the Railway Administrations, a railway worker was expected to be a "good, honest and conscientious member of the railway staff and an exemplary citizen of the country.

IR was also seen to be an employer with many attractions. IR employees enjoy fringe benefits such as free passes and concessional tickets to travel the length and breadth of the country. These cover the employee and her/his dependent family at all levels. Officers often quoted that these were seen to be factors that attracted them to join the railway service. Another motivational or pull factor to join the railway service was the ability to maintain a work-life balance in comparison to the private sector and also an opportunity for a fixed career 
progression. Hence though the remuneration was lower than in the private sector, railway employees enjoy job security at all levels except under exceptional cases in an otherwise highly volatile job market. The low level of staff turnover was also evident from the number of pensioners who were expected to be around one million, which almost equates to the number of serving employees. It was also learnt that in the current economic climate there has been an increase in the number of applications for jobs in IR as it was seen as a job for life.

\section{CROSSROADS FOR IR}

IR was making losses and looked unsustainable as a part of the public sector. ${ }^{41}$ By the year 2000, IR had taken 21 loans from the World Bank totaling US $\$ 2.2$ billion. ${ }^{42}{ }^{43}$ However in recent years it was reporting huge profits close to US\$5 billion over last 4 years. ${ }^{44} 4546$ This prompted an Ex-General Manager of a railway zone to say

"Railways are at the crossroads. Economy is looking up and the winds of change are blowing". 47

Recently a book titled 'Bankruptcy to billions' authored by Kumar and Mehrotra, (2009) described the transformation of the IR wherein they argue that from a position of "near bankruptcy' in 2001, with a cash balance of only $\$ 83$ million (US), it was converted into profit, with substantial surpluses of $\$ 3.5$ billion in 2006 and $\$ 6$ billion in 2008 . Without its true assets, which were its people, the IR would not have achieved this 'transformational turnaround' in its economic performance. ${ }^{48} 495051$ The Economist, (2003) reported that a special committee on the IR was quoted to have said that it was "one of the most studied institutions on the planet". 


\section{WAY FORWARD}

Though IR was a commercial enterprise, albeit a Government PSU organization, it was also very much what one officer called a 'social cause' - where 1.3 million people were gainfully employed with a 'job for life'. This translates into a stable and better society and adds value to the economy. Recruitment and selection in IR was seen to be rigorous, structured and formalized. IR remains an attractive job proposition, seen as an employer of choice where millions vie for a job. They have decent pay grades and the latest sixth pay commission has announced certain policies that would attract and retain talent. Identification of future staff needs and rightsizing by 'benchmarking' and 'workforce-planning' were proactive and strategic steps on part of the railways have added value to the bottom line of their financial performance. Training was seen to be very important and available at all levels as it was considered as an investment and not a cost. Apart from internal training centres, the IR also train their staff at national and international institutes of repute. Another interesting aspect was the rising payroll/cost on staff and pensions bills - which was seen to directly affect IR's finances. To offset this cost, IR has decided to pursue $1 \%$ annual reduction in its staff.

While investigating the changes in the HR practices and the role of HR in IR's turnaround strategies, evidence suggested an evolution of HR practices over a period of time. Some of them includes increased transparency in recruitment and selection, declining scope for corruption, increased pay levels of all employees (last two pay commissions), strong initiatives to attract and retain key talent, personal development initiatives (includes a 2-year study leave and a 2-year child-care leave for female employees), and globally respected quality training. As frequency of accidents happening was always a challenge, safety remains the paramount within IR. Benchmarking' within its workforce management, supply chain management, operations management, logistics management - to name few - were being 
introduced in the railways as latest management practices. Image and culture of a typical PSU were being slowly shed as the benefits of global economy were seen to be trickling down. As IR was now noticed on the global stage with the world's eyes on them, IR officers wished it to be seen as a professional and transparent organization [motivation for implementing the 'right to information act' (RTI) in IR].

Pay being an important ingredient and a key motivator for staff; it was highly difficult to manage it within a large PSU such as the IR. The fifth and sixth pay commissions realized this and have designed the pay packets of the railway staff accordingly. Hence it was not surprising that it was during this period that the financial turnaround in its performance took place. Other important and interesting changes were taking place in terms of payroll management. At present IR plans to outsource its payroll and thinks of implementing ERP systems for improved and efficient services. However both these, and not surprisingly, were being resisted by the personnel staff due to fear of job losses and redundancies.

Chief Personnel Officer (CPO) of each IR zone under the ministry of railways plan to procure a human resources management system (HRMS) and other modules for integrating and automating its payroll, accounting, and pension functions. CPO aims to have a centralized system for managing its staff better. The organization plans to spend around $\$ 1.5$ billion over the next two to three years on technology. IT giants such as Wipro and Tata Consultancy Services were seen to be competing for this contract. Interestingly and opposite to the outsourcing plan as seen above - a recent development initiated by the ministry of railways to automate in-house all operational and personnel practices and elimination of the age-old manual and paperized 'record system' of maintaining employee records. It proposes to automate the entire IR system (listed in exhibit 9), with a centralized enterprise resource 
planning (ERP) system. It has been proposed to make this system totally user-friendly and operational in three languages such as English, Hindi and the respective regional language of the state e.g., Marathi in Maharashtra, Gujarati in Gujarat and so on. This initiative was expected to bring about integration of data at a national level. But, there was some resistance from the employees to accept this system due to fear of job losses and security. It has the possibility to be implemented as a centralized all-India ERP system, for central access to all personnel and office related information, with a central monitoring mechanism. Currently each division or headquarter may have its own in-built internal personnel management system and thus there were no link between the systems. Western Railway Head Quarters currently has two internal human resource information systems (HRIS) namely:

- Personnel management information system (PMIS) - which will cover all employee related information such as cadre strength; promotion; posting; staff on roll; rosters; leave records and so on

- PRIME system - which can be used for payroll, settlement and income tax related information

In Bilaspur division of the South Eastern zone, the PMIS System has been integrated with the PRIME'. It was also widely felt by the officers that the overall ERP implementation impact will be seen within the next 5-8 year's timeframe. The Western Railways has been chosen by the railway ministry for pilot implementation of ERP at a national level.

The Railway Board plans to commence operations of the ERP system by planting computer kiosks at various stations and terminals across India. This work has already commenced with creation of employee - related service kiosks at various divisions of the IR. These kiosks allow the employees to easily access their service related information instead of approaching 
the personnel department to resolve even the smallest queries. IR also proposes to launch a 'call centre' to manage internal customer (employee) related queries. As these initiatives were resisted by the personnel staff, CPO's have to devise policy documents and revisit the existing HR practices for adapting them to remove the resistance exerted by the employees on implementation of the change initiatives mentioned. 


\section{Exhibits}

Exhibit 1: Number of staff and expenditure on staff in IR from 1950-2010.

\begin{tabular}{|c|c|c|c|c|c|}
\cline { 2 - 6 } \multicolumn{1}{c|}{} & \multicolumn{4}{c|}{ Number of staff as on 31st March (in thousands) } & Expenditure on staff \\
\hline Year & Groups A \& B & Group C & Group D & Total & (INR in crore) \\
\hline $1950-51$ & 2.3 & 223.5 & 687.8 & 913.6 & 113.8 \\
\hline $1960-61$ & 4.4 & 463.1 & 689.5 & $1,157.0$ & 205.2 \\
\hline $1970-71$ & 8.1 & 583.2 & 782.9 & $1,374.2$ & 459.9 \\
\hline $1980-81$ & 11.2 & 721.1 & 839.9 & $1,572.2$ & $1,316.7$ \\
\hline $1990-91$ & 14.3 & 891.4 & 746.1 & $1,651.8$ & $5,166.3$ \\
\hline $2000-01$ & 14.8 & 900.3 & 630.2 & $1,545.3$ & $18,841.4$ \\
\hline $2008-09$ & 16.4 & 913.3 & 456.3 & $1,386.0$ & $39,940.9$ \\
\hline $2009-10$ & 16.7 & 926.5 & 418.9 & $1,362.1$ & $51,719.4$ \\
\hline $2010-11$ & 16.8 & $1,076.9$ & 234.5 & $1,328.2$ & $53,706.9$ \\
\hline
\end{tabular}

Source: Indian Railways Year Book 2010-11.

Exhibit 2: Details of number of passengers and earnings at sub-urbans for few key zones (for March 2013).

\begin{tabular}{|l|c|c|}
\hline \multicolumn{1}{|c|}{ Railway Zone } & $\begin{array}{c}\text { No. of Passengers } \\
\text { (in millions of INR) }\end{array}$ & $\begin{array}{c}\text { Earnings (in } \\
\text { crores of INR) }\end{array}$ \\
\hline Central Railway (CR) & 119.78 & 62.13 \\
\hline Eastern Railway (ER) & 88.62 & 44.62 \\
\hline Southern Railway (SR) & 33.55 & 15.43 \\
\hline South Central Railway (SC) & 3.87 & 2.02 \\
\hline South Eastern Railway (SER) & 11.50 & 7.65 \\
\hline Western Railway (WR) & 106.05 & 56.70 \\
\hline Metro & 15.85 & 8.24 \\
\hline Total IR & 379.22 & 196.79 \\
\hline
\end{tabular}

Source: 2013 March Gross Earnings and Passenger Booked, Statistics \& Economics Directorate. 


\section{Exhibit 3: Organizational Structure of IR}

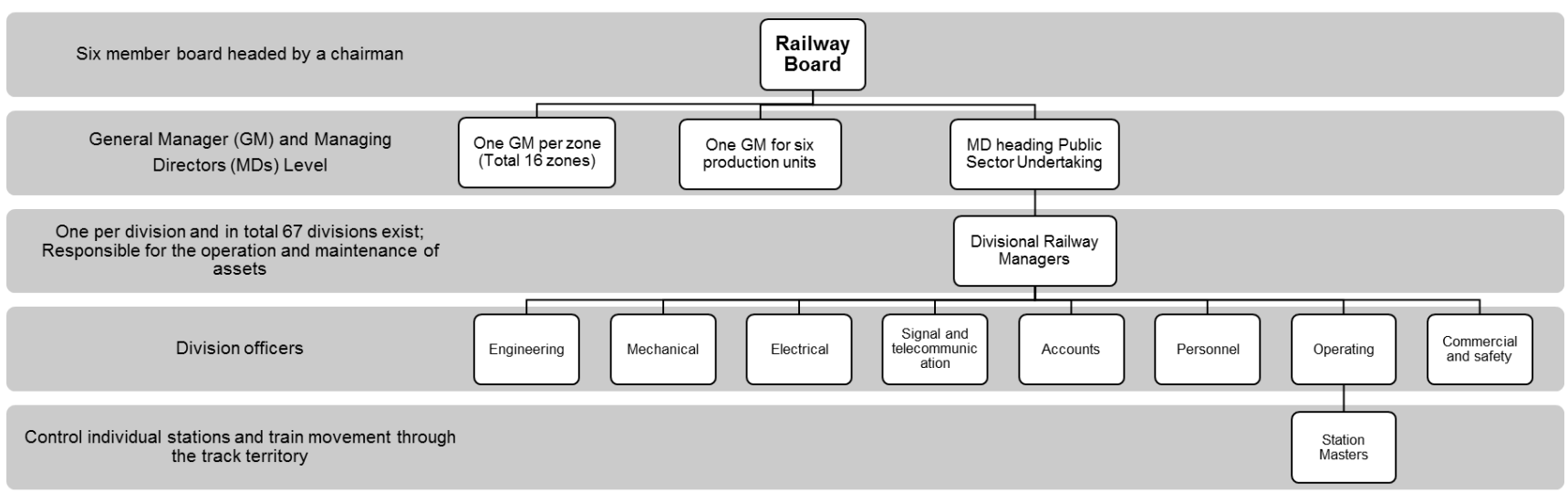

Source: Compiled by authors from interviews.

Exhibit 4: Four classes of IR employees.

\begin{tabular}{|c|l|l|}
\hline Class & \multicolumn{1}{|c|}{ Description } & Category \\
\hline IV & $\begin{array}{l}\text { Selection for these posts was done by the railway administrations through } \\
\text { Selection Boards. Employment notices were issued locally and the } \\
\text { assistance of the local employment exchange were sought for getting } \\
\text { adequate number of suitable candidates. This category constitutes technical } \\
\text { and other maintenance staff. }\end{array}$ & $\begin{array}{l}\text { Non- } \\
\text { gazetted } \\
\text { staff }\end{array}$ \\
\hline III & $\begin{array}{l}\text { These posts were usually made through the Railway Service Commissions } \\
\text { by open competition on all India bases. In this category, officers were } \\
\text { clerical and supervisory staff. }\end{array}$ & $\begin{array}{l}\text { Non- } \\
\text { gazetted } \\
\text { staff }\end{array}$ \\
\hline I \& II & $\begin{array}{l}\text { Recruited through competitive examination held by the Union Public } \\
\text { Service Commission (UPSC - Civil Services). }\end{array}$ & $\begin{array}{l}\text { Gazetted } \\
\text { staff }\end{array}$ \\
\hline
\end{tabular}

Source: Compiled by authors from interviews. 
Exhibit 5: Different recruitment and selection routes of officers for classes I and II in different departments/branches or disciplines.

\begin{tabular}{|c|c|}
\hline $\begin{array}{l}\text { Departments } \\
\text { /branches or } \\
\text { disciplines }\end{array}$ & Description \\
\hline $\begin{array}{c}\text { The Indian } \\
\text { Railway } \\
\text { Traffic } \\
\text { Service }\end{array}$ & $\begin{array}{l}\text { This branch of the IR looks after transportation and commercial matters pertaining to } \\
\text { transportation. The branch was therefore divided into two divisions: } \\
\text { a) The commercial division: This division handles all commercial responsibilities } \\
\text { like ticket checking, catering, administration and management of stations, reservation, } \\
\text { announcements on the platforms, marketing, public relations etc. } \\
\text { b) The operations division: This division deals with controlling movement of trains. } \\
\text { Keeping a check on incoming and outgoing trains, detachment or attachment of } \\
\text { wagons, etc., were the responsibilities of this division. The posts and promotions } \\
\text { differ slightly as per the selection grade. When an officer reaches the senior } \\
\text { administrative grade, he or she was given the post of Chief Commercial/ Operations } \\
\text { Manager. }\end{array}$ \\
\hline $\begin{array}{c}\text { India } \\
\text { Railway } \\
\text { Accounts } \\
\text { Service }\end{array}$ & $\begin{array}{l}\text { This branch of the railway services was engaged in handling the accounting and } \\
\text { finance operations of the IR. Working in this branch would entail dealing with } \\
\text { financial transactions and hence a thorough knowledge of accounting procedures and } \\
\text { related practices would prove an asset for officers who opt for this branch of the IR. } \\
\text { An officer in the senior grade was given the charge of a zone and the post of a } \\
\text { Financial Advisor-cum-Chief Accounts Officer. At this post, the officer carries the } \\
\text { overall responsibility for accounts for the whole zone. }\end{array}$ \\
\hline $\begin{array}{c}\text { Indian } \\
\text { Railway } \\
\text { Personnel } \\
\text { Service }\end{array}$ & $\begin{array}{l}\text { As the name indicates, officers in this division handle all matters related to } \mathrm{HR} \text { and } \\
\text { personnel such as recruitment and selection, promotions, training, welfare activities, } \\
\text { transfers, increments, and disciplinary actions. }\end{array}$ \\
\hline $\begin{array}{l}\text { Railway } \\
\text { Protection } \\
\text { Service/Rail } \\
\quad \text { way } \\
\text { Protection } \\
\text { Force (RPF) }\end{array}$ & $\begin{array}{l}\text { This branch of the Indian Railway services was entrusted with the task of maintenance } \\
\text { of law and order on trains and on premises owned and used by the IR. They were also } \\
\text { entrusted with the complete safety of all railway assets and staff. Each zone's Chief } \\
\text { Security Commissioner was responsible for recruitment and selection of 'inspectors' } \\
\text { and 'constables' in the RPF. The top officers in the RPF were deputed from the Indian } \\
\text { Police Services (IPS), a branch of the UPSC - the civil services of the country. }\end{array}$ \\
\hline $\begin{array}{l}\text { Railway } \\
\text { Engineering } \\
\text { Services }\end{array}$ & $\begin{array}{l}\text { This was the technical side of the railway services and remains engaged in activities } \\
\text { like construction and planning of railway tracks, bridges and buildings. There were } \\
\text { branches in this division like the Indian Railway Service of Electrical Engineers and } \\
\text { the Indian Railway Service of Mechanical Engineers, to name a few. For the selection } \\
\text { of mechanical engineers, a 'Special Class Railway Apprenticeship' examination was } \\
\text { held. The chosen candidates were given four-year probationary training. }\end{array}$ \\
\hline $\begin{array}{l}\text { Indian } \\
\text { Railway } \\
\text { Medical }\end{array}$ & $\begin{array}{l}\text { The appointment of doctors for railway hospitals as Assistant Divisional Medical } \\
\text { Officers, Divisional Medical Officers, Specialists Surgeons, Assistant Divisional } \\
\text { Dental Surgeons/Divisional Dental Surgeons and Miscellaneous gazetted categories }\end{array}$ \\
\hline
\end{tabular}




\begin{tabular}{|c|l|}
\hline Services & $\begin{array}{l}\text { directly connected with Railway Medical Services were through a combined medical } \\
\text { services examination. Vacancies were calculated and indents placed with the UPSC } \\
\text { for medical recruitment in Group 'A' for the Railways. In certain cases part-time } \\
\text { general duty doctors and part-time specialists were appointed from the open market. }\end{array}$ \\
\hline
\end{tabular}

Source: Compiled by authors from interviews.

Exhibit 6: Objectives of Railway Recruitment Control Board (RRCB).

\begin{tabular}{|c|}
\hline Formulation of policy in regard to recruitment procedures \\
\hline Monitoring the activities of all including expenditure incurred for recruitment \\
\hline Evaluating the performance of RRB's, and advise them on priorities \\
\hline Organizing and managing information system for monitoring the work done by RRBs. \\
\hline
\end{tabular}

Source: Compiled by authors from interviews.

Exhibit 7: Seven 'Centralized Training Institutes' (CTIs) of IR.

\begin{tabular}{|l|}
\hline Railway Staff College, Vadodara \\
\hline Indian Railways Institute of Civil Engineering, Pune \\
\hline Indian Railways Institute of Signal Engineering and Telecommunications, \\
Secunderabad \\
\hline Indian Railways Institute of Mechanical and Electrical Engineering, Jamalpur \\
\hline Indian Railways Institute of Electrical Engineering, Nasik \\
\hline Indian Railways Institute of Transport Management, Lucknow \\
\hline Jagjivan Ram Railway Protection Force Academy, Lucknow. \\
\hline
\end{tabular}

Source: Compiled by authors from interviews. 
Exhibit 8: Classification of IR employees based on the hours of work.

\begin{tabular}{|c|c|}
\hline Classification & Hours of work \\
\hline Continuous & $\begin{array}{l}\text { The employment of a railway servant was said to be 'continuous' except } \\
\text { when it was excluded or has been declared to be essentially intermittent or } \\
\text { intensive (shall not be employed for more than } 54 \text { hours a week on an } \\
\text { average in a two-weekly period of } 14 \text { days) }\end{array}$ \\
\hline $\begin{array}{l}\text { Essentially } \\
\text { intermittent }\end{array}$ & $\begin{array}{l}\text { The employment of a railway servant was said to be 'essentially intermittent' } \\
\text { when it has been declared to be so by the prescribed authority on the ground } \\
\text { that the daily hours of duty of the railway servant normally include periods } \\
\text { of inaction aggregating to } 50 \% \text { or more including at least one such period of } \\
\text { not less than one hour or two such periods of not less than half an hour each) } \\
\text { in a tour of twelve hours duty (on the average over } 72 \text { consecutive hours), } \\
\text { during which the railway servant may be on duty, but was not called upon to } \\
\text { display either physical activity or sustained attention (shall not be employed } \\
\text { for more than } 75 \text { hours in any week). }\end{array}$ \\
\hline Ex & $\begin{array}{l}\text { The employment of a railway servant was said to be 'excluded', if he } \\
\text { belongs to any one of the following categories, namely: } \\
\circ \text { railway servants employed in a managerial or confidential capacity } \\
\circ \text { armed guards or other personnel subject to discipline similar to that of } \\
\text { any of the armed police forces } \\
\circ \text { staff of the railway schools imparting technical training of academic } \\
\text { education } \\
\circ \text { such staff as may be specified as supervisory under the rules } \\
\circ \text { such other categories of staff as may be prescribed }\end{array}$ \\
\hline Intensive & $\begin{array}{l}\text { The employment of a railway servant was said to be 'intensive' when it has } \\
\text { been declared to be so by the prescribed authority on the ground that it was } \\
\text { of strenuous nature involving continued concentration or hard manual labour } \\
\text { with little or no period of relaxation (shall not be employed for more than } 45 \\
\text { hours a week on an average in a two-weekly period of } 14 \text { days). }\end{array}$ \\
\hline
\end{tabular}

Source: Compiled by authors from interviews. 
Exhibit 9: Proposed automation systems in the entire IR system with a centralized ERP.

\begin{tabular}{|c|}
\hline Annual confidential report (performance appraisal report) \\
\hline Leave management \\
\hline House building advance loans \\
\hline Provident fund advances \\
\hline Pay bill processes \\
\hline Promotion processes \\
\hline Training management \\
\hline PC/car/scooter advances \\
\hline Recruitment \\
\hline Transfers \\
\hline Grievances \\
\hline Penalties \\
\hline Retirement management \\
\hline Staff benefit fund \\
\hline Court cases \\
\hline Holiday homes \\
\hline
\end{tabular}

Source: Compiled by authors from interviews. 


\section{References}

\footnotetext{
${ }^{1}$ Thorner, Daniel. "The pattern of railway development in India." The Journal of Asian Studies 14.02 (1955): 201-216.

${ }^{2}$ Key reports on Indian Railways can be accessed from the following links: (a) Monthly report on gross earning and freight revenue -
}

http://www.indianrailways.gov.in/railwayboard/view_section.jsp?lang=0\&id=0,1,304,366,554,818,821; (b)

Annual Reports \& Accounts, Indian Railways Year Book, and Annual Statistical Statements -

http://www.indianrailways.gov.in/railwayboard/view section.jsp?lang=0\&id=0,1,304,366,554,1272; (c) Report of the Comptroller and Auditor General of India -

http://www.performance.gov.in/sites/default/files/departments/railways/CAG\%20Report\%2011\%20of\%202013. pdf; and finally (d) Ministry of Railways Vision, Mission, Objectives \& Outcomes along with CAG Report http://performance.gov.in/?q=ministry/railways. Last accessed on 20 November 2015.

${ }^{3}$ Macpherson, W. J. "Investment in Indian railways, 1845-1875." The Economic History Review 8.2 (1955): 177-186.

${ }^{4}$ The Economist, 2003

${ }^{5}$ Srinivasan, Roopa, Manish Tiwari, and Sandeep Silas, eds. Our Indian Railway: Themes in India's Railway History. Foundation Books, 2006.

${ }^{6}$ Thorner, Daniel. "Great Britain and the development of India's railways." The Journal of Economic History 11.04 (1951): 389-402.

${ }^{7}$ Kerr, Ian J. Engines of change: the railroads that made India. Greenwood Publishing Group, 2007.

${ }^{8}$ Kerr, Ian J. Engines of change: the railroads that made India. Greenwood Publishing Group, 2007.

${ }^{9}$ Malik, P. K. "Improvement of Railway Finances: Hiving off Non-core activities." (2007).

${ }^{10}$ Thompson, Louis S. "Liberalization and commercialization of the world's railways: progress and key regulatory issues." International Transport Forum 2009, Transport For A Global Economy, Challenges and Opportunities In The Downturn International Transport Forum, Forum Paper 2009-6, Oecd/Itf, Paris., (2009).

${ }^{11}$ Morris, Morris David, and Clyde B. Dudley. "Selected Railway Statistics for the Indian Subcontinent (India, Pakistan and Bangladesh), 1853-1946-7." Artha Vijnana 17.3 (1975): 202-204.

12 Kerr, Ian J. Building the Railways of the Raj, 1850-1900. Oxford University Press, 1995.

${ }^{13}$ Hurd, John., and Ian J. Kerr. "Railway Management and Railway Employees in Colonial India." Railway Management and its Organisational Structure: Its Impact on and Diffusion into the General Economy (1998): 103-117.

${ }^{14}$ Ramani, K. V., and B. K. Mandal. "Operational planning of passenger trains in Indian Railways." Interfaces 22.5 (1992): 39-51.

15 Indian Railway Budget Report, 2008/2009, and 2009/2010.

${ }^{16}$ Indian Railways Year Book 2010-11. Available at

http://www.indianrailways.gov.in/railwayboard/uploads/directorate/stat_econ/yearbook10-11/Year_book_10-

11 eng.pdf (last accessed on 20 Nov 2015)

${ }^{17}$ Richardson, Pikay, and Ajit Nigam. "New Technology Introduction and Implementation: The Case of Paging Technology in the Ratlam Division of Indian Railways." Creativity and Innovation Management 8.4 (1999): 233-241.

${ }^{18}$ Dalvi, M. Q. "Should Indian Railways be Privatised?." Economic and Political Weekly (1995): 103-112.

${ }^{19}$ Goulding, A. J. "Retreating from the commanding heights: privatization in an Indian context." Journal of International Affairs 50.2 (1997): 581-602.

${ }^{20}$ Galenson, Alice, and Louis S. Thompson. "Forms of private sector participation in railways." TWU Papers No. 9, The World Bank, Washington, DC. (1993).

${ }^{21}$ Sriraman, Siva. "Indian Railway Finances: Critical Issues and Emerging Options." Economic and Political Weekly (2000): 1029-1034.

${ }^{22}$ Kulsreshtha, Mudit, and Barnali Nag. "Structure and dynamics of non-suburban passenger travel demand in Indian railways." Transportation 27.2 (2000): 221-241.

${ }^{23}$ Srivastava, Shirish C. "Managing core competence of the organization." Vikalpa 30.4 (2005): 49.

${ }^{24}$ Indian Railway Budget Report, 2008/2009 and 2009/10

${ }^{25}$ Gross Earning On Originating Basis. Available at

http://www.indianrailways.gov.in/railwayboard/uploads/directorate/stat_econ/MTHSTAT/2015/Month_Sept_20

15.pdf (accessed on 20 November 2015).

${ }^{26}$ Indian Railway Budget Report, 2008/2009 
${ }^{27}$ Indian Railways Annual Report \& Accounts 2010-11. Available at http://www.indianrailways.gov.in/railwayboard/uploads/directorate/stat_econ/Annualreport1011/Annual_report_10-11_eng.pdf (last accessed on 20 Nov 2015)

${ }^{28}$ Indian Railways Annual Report \& Accounts 2010-11. Available at http://www.indianrailways.gov.in/railwayboard/uploads/directorate/stat_econ/Annualreport1011/Annual report 10-11_eng.pdf (last accessed on 20 Nov 2015)

${ }^{29}$ Eleventh Five Year Plan Report, 2007-2012

${ }^{30}$ Twelfth Five Year Plan Report, 2012-2017. Volume 1 available at http://www.iritm.indianrailways.gov.in/uploads/files/136514439384912\%20Twelfth\%20Five\%20Year\%20Plan\%20Vol\%201.pdf and Volume 2 available at http://agridr.in/pdf/12th_plan_GOI_2012-17/vol_2.pdf. Last accessed on 13 November 2015.

${ }^{31}$ Pereira, V. (2015) 'Managing people in the world's largest commercial employer: an exploratory study on Indian Railways', Int. J. Indian Culture and Business Management, Vol. 10, No. 2, pp.136-156.

${ }^{32}$ Pereira, V. (2011) Insights into managing people in the world's largest commercial employer- the Indian railways. HR Bulletin: Research and Practice, Vol. 6, No. 1, pp. 3-5.

${ }^{33}$ Indian Railway Budget Report, 1972

${ }^{34}$ Indian Railway Budget Report, 2008/2009

${ }^{35}$ Hardgrave, R. L. (1993). India: The dilemmas of diversity. Journal of Democracy, 4(4), 54-68.

${ }^{36}$ Zimmermann, K.A. (2015) Indian Culture: Traditions and Customs of India. Available at http://www.livescience.com/28634-indian-culture.html (last accessed on 16 November 2015)

${ }^{37}$ Hardgrave, R. L. (1993). India: The dilemmas of diversity. Journal of Democracy, 4(4), 54-68.

${ }^{38}$ Mondel, P. Essay on the Different Forms of Diversity in India. Available at http://www.yourarticlelibrary.com/india-2/essay-on-the-different-forms-of-diversity-in-india/4001/ (last accessed on 16 November 2015)

${ }^{39}$ Mondel, P. Essay on the Different Forms of Diversity in India. Available at http://www.yourarticlelibrary.com/india-2/essay-on-the-different-forms-of-diversity-in-india/4001/ (last accessed on 16 November 2015)

${ }^{40}$ Thunuguntla, J. (2009). Indian Wealth Distribution-On Geographic Basis-Nov 2009. Available at SSRN

1750791 .

${ }^{41}$ Ahluwalia, M. S. "Economic reforms in India since 1991: has gradualism worked?." The Journal of Economic Perspectives 16.3 (2002): 67-88.

42 Thompson, Louis. "Changing railway structure and ownership: is anything working?." Transport Reviews 23.3 (2003): 311-355.

${ }^{43}$ Thompson, Louis S. "Liberalization and commercialization of the world's railways: progress and key regulatory issues." International Transport Forum 2009, Transport For A Global Economy, Challenges and Opportunities In The Downturn International Transport Forum, Forum Paper 2009-6, Oecd/Itf, Paris., (2009).

${ }^{44}$ Veni, L. Krishna, and Sangita Ghosh. "Performance of a Public Enterprise-The Indian Railways." The IUP Journal of Public Administration 1.1 (2005): 71-87.

${ }^{45}$ Raghuram, G. "'Turnaround'of Indian Railways: A Critical Appraisal of Strategies and Processes." (2007)

${ }^{46}$ Indian Express, 2010; IRFC website

${ }^{47}$ Banerji, Ashutosh Kumar. "Railways and Rolling Stock Engineers-Challenges Ahead." Technical Note (2005). Available at http://www.irsme.nic.in/files/RLY_RLE_AB.pdf (last accessed on 23 September 2014).

${ }^{48}$ Analoui, Farhad. "Management skills and senior management effectiveness." International Journal of Public Sector Management 8.3 (1995): 52-68.

${ }^{49}$ Nelson, E. "Indian Railways runs right under Yadav's leadership." (2007). Available at http://www.washingtontimes.com/world/20060414-110533-6362r.htm (last accessed on 23 September 2009).

${ }^{50}$ George, Sajeev Abraham, and Narayan Rangaraj. "A performance benchmarking study of Indian Railway zones." Benchmarking: An International Journal 15.5 (2008): 599-617.

${ }^{51}$ Gupta, Desh, and Milind Sathye. "Turnaround of the Indian Railways: a public ownership saga." International Journal of Public Policy 5.1 (2010): 86-102. 